\title{
The Role of Metformin in the Treatment of Type 2 Diabetes and Obesitys
}

\author{
Mira H. Vuković
}

Education Center, General Hospital Valjevo, Valjevo, Serbia

\section{SUMMARY}

Topic: Mutual association and connection study between the obesity, visceral obesity, insulin desensitation (with the conesquential hyperinsulinemia), type 2 diabetes, dyslipoproteinemia and anthropometric characteristics of the patients with the metabolic syndrom are the subject of many epidemiological studies. However, it is noticed that there are certain disagreements and contradictions in defining the anthropometric and metabolic risk factors for the occurance of the cardiovascular, cerebrovascular and other vascular diseases, especially in population of the obese patients with type 2 diabetes.

Topic position in medical public: Theoretically, metformin achieves a good glicoregulation preciselyinthe visceral obese patients. This is explained by a higher glucometabolic activity of the visceral adipose tissue in regard to the subcutenaus tissue.

Futher action: More efficient reduction of the visceral adipose tissue inpatients with achieved better glucoregulation, under the affection of the metformin is a result of its complex effect mechanism. Metformin plays a significant role in the reduction of the cardiovascular risk that comes from a higher visceral obesity, parallel to the achievement of the good glicoregulation in obese, type 2 diabetes patients.

Keywords: metformin, diabetes mellitus, type 2, obesity, adipose tissue

\section{TOPIC}

For the obesity development, as well as for the development of the mentioned metabolic deseases, answering how or in which way does it come to the increasement of the body adipose tissue has a great clinical significance. There are two ways of increasing body adipose tissue in obesity - proliferation or adipose hypertrophy.

\section{TOPIC POSITION IN MEDICAL PUBLIC}

There are reports that say that the adipose in type 2 diabetes persons and with positive calory balance, compared to the obese persons without the diabetes, have lower chance for fat storage with cellular proliferation because of the decreased genes expression responsible for the adipogenesis [1,2]. However, clinical significance in the obesity patogenesis does not refflect only in the fact how, but also where does the body adipose accumulate and store $[1,3,4]$. According to the place - region where the adipose accumulates, the adipose tissue is divided to the visceral and subcutenaus adipose tissue. The visceral adipose tissue is adipose more 
metabolically active compared to the subcotenaus adipose tissue. Bigger metabolic activity of the visceral adipose tissue, compared to the subcutaneous, is reflected in the schedule and the amount of the receptors in the adipocytes, disballance between the lipogenesis and lipolysis, difference in the secretion of the adipokines, cytokines and other mediators of inflammation, as well as the difference in the hormone and protein release [3].

The appearance of the visceral adipose tissue in the omentum, mesentery, liver, muscles, pericardially and other organs is marked as ectopic and often combines with the high insulin concetration in blood and insulin resistence that is measured by hyperinsulinemic euglycemic clamp or other techincs that measure fast responses of the aimed organs, primarily muscels, to the insulin action $[5,6]$. It is also shown that the acummulation of the visceral adipose tissue in abdomen is combined with the accelerated aterosclerosis development [7].

The connection od the insulin resistence and excess accumulation od the visceral adipose tissue still has not been clarified. There are few theories about the connection between the insulin resistence and overaccummulation of the visceral adipose tissue, one of which is "portal" or "lipolitic" theory. This theory implies that the intra-abdominal visceral adipose tissue has anatomic and metabolic charachteristics that are unique compared to the adipose tissue of other localization, and, which is very interesting, it is especially regarded to the regions that are drained via the portal circulation (omental and mesenteric adipose tissue) [8].

According to this theory, the connection between the insulin resistence and visceral adipose tissue is in the fact that the visceral adipose tissue has a bigger activation of the $\beta 3$ adrenergic receptor with polymorphism of the gene allele responsible for the expression of $\beta 3$ receptors [9]. Bigger $\beta 3$ receptors activity leads to the increasement of the lipolitic activity, circulating non-esterfied adipose acids increase, dislipoproteinemia (increased levels of triglycerides with reduced levels of high-density cholesterol) and insulin resistance with a consequent reduction in glucose tolerance.

Alternative to the "portal theory" is "hormone-inflammatory theory" in whose base is that the visceral adipose tissue is rich in macrophages that increasingly produce pro- inflammatory cytokines, such as tumor necrosis factor alpha (TNF- $\alpha$ ) and interleukin-6, while leading to the decreased protective adipokines secretion, among which adiponectin should be noted [10].

Also, it was demonstrated in animal models that visceral fat affects hormone production higher resistin, which got its name based on being established that it causes resistance to insulin [11]. For mentioned abdominal visceral fat it has been presented, both in humans and in animal models, that these tissues compared to the subcutaneous adipose tissue produce significantly more interleukin-6, [12] while the excessive secretion of TNF- $\alpha$ could be produced only in animals, but not in the human population [13]. It has been shown that interleukin- 6 possess great induction potential of C-reactive protein (CRP) in the liver, so the interleukin- 6 and CRP have become important predictors of visceral obesity, insulin resistance syndrome and type 2 diabetes [14]. Studies that have pointed to the importance of the links between genetic factors, excessive food intake, reduced physical activity, insulin resistance, visceral obesity, inflammation and endothelial dysfunction of blood vessels in the development of atherosclerosis in patients with type 2 diabetes are especially important [15].

Also in animal models has been shown that by specific inhibitors of tyrosine kinases (substances among which there are also some drugs that are mainly used in certain leucosis treatment, but are also being tested the treatment of type 2 diabetes resistant to other forms of treatment) reduces insulin resistance and insulinemia [16]. It was found that their use increases the takeover and use of glucose, associated with the reduction of proinflammatory cytokines and proliferation of macrophages in the mesenteric adipose tissue. All of this was accompanied by a reduction of the insulin receptor substrate 1 , which has be proven, next to the tyrosine kinase of the insulin, that can be phosphorylated and serine / threonine kinases, activated by mediators of chronic inflammation or stress.

Certain newly discovered substances with hormonal action, such as visfatin, which is largely secreted in visceral adipose tissue, has been shown to act like insulin via a tyrosine kinase, and that visfatin and insulin have equal insulin effect [17]. It has also been suggested that there is no competition between visfatin 
and insulin, so it was concluded that they bind to different subunits of the insulin receptor.

Great advance in the research of the pathogenetic link between insulin resistance, central type obesity, intra-abdominal obesity, chronical inflammation, atherosclerosis, dyslipoproteinemia and type 2 diabetes, has an increasing clinical importance, for at least two reasons. The first reason certainly is awareness of the role of intra-abdominal visceral adipose tissue in insulin resistance and type 2 diabetes, which led to the improvement and development of new anthropometric measurement methods and visceral obesity diagnosis in the general human population of different age, gender, ethnicity and race $[18,19]$. While some authors emphasize the importance of the morphological measurement of visceral adipose in patients with type 2 diabetes with nuclear magnetic resonance imaging, computed tomography or ultrasound, [19] others emphasize the ease of measurement of waist circumference as a measure of abdominal obesity, but also the most important predictor of vascular events in these patients [20]. The latter authors showed that in patients with type 2 diabetes and waist circumference $>90 \mathrm{~cm}$ (for men) or $>85 \mathrm{~cm}$ (for women), as well as with the level of serum triglycerides $\geq 2 \mathrm{mmol} / \mathrm{L}$ (hypertriglyceridemic waist), multiply increases the risk of a cardiovascular disease.

Second, but not less important reason to clarify the role of increased visceral obesity in type 2 diabetes is that these findings started to apply critically in monitoring the effects of pharmacotherapy drugs in type 2 diabetes and its prevention, but also in control of its nonpharmacological treatment, which primarily involves the implementation of strict dietary measures with the programmed physical activity increase [21-23].

In newly diagnosed type 2 diabetes patients first step in the treatment is a change of lifestyle that is reflected in the reduction of patient body weight (if overweight) and increasing physical activity. However, such therapeutic measure, even if it leads to a reduction in glycated hemoglobin (HbA1c) by $1-2 \%$, it becomes insufficient to maintain the achieved glucometabolical effect already in the first year of non-pharmacological intervention [24].

The next step in the type 2 diabetes treatment is conducting therapy with metformin, which is only contraindicated in patients with renal insufficiency (creatinine con- centrations $>132 \mathrm{mmol} / \mathrm{L}$ for men and $>124$ $\mathrm{mmol} / \mathrm{L}$ for women) [25]. The expected reduction in the level of HbAlc in patients with type 2 diabetes on metformin monotherapy is $1 \%-2 \%[26,27]$. Metformin is an oral anti-diabetic agent from the group of biguanides. The bioavailability of metformin is $50 \%-60 \%$. It is absorbed mainly from the small intestine, and estimated time of resorption him 0.9 hours to 2.6 hours. After 1-2 hours from the oral dose taken from $500 \mathrm{mg}-1000 \mathrm{mg}$, maximum drug concentrations in plasma are $1-2 \mu \mathrm{g} / \mathrm{mL}$. About $90 \%$ of metformin is eliminated in the urine within 12 hours. Is evenly distributed in all tissues, in concentrations close to those in the peripheral plasma, while it achieves high concentrations in the liver and kidneys. Metformin achieves the highest concentrations in the salivary glands and in the intestine wall.

The metformin treatment increases insulin sensitivity, which is reflected by reducing fast glucose and insulin circulating concentrations. Metformin has no effect in the absence of insulin [28]. In patients with type 2 diabetes, the effect in reducing the glycemia by metformin is mainly explained by the mechanism of reducing hepatic production and increasing peripheral glucose uptake. Several other mechanisms of metformin action also contribute to the reduction of blood glucose, such as increasing intestinal glucose utilization and reducing adipose acid oxidation. Metformin decreases glucose production in the liver in patients with type 2 diabetes, in which it must be borne in mind that this is a very important mechanism of action on reducing fast glucose [29].

In isolated liver cells metformin increases suppressing gluconeogenesis by insulin and lowers glucagon-stimulated gluconeogenesis [30]. In most studies, metformin also increases the availability of glucose which was confirmed by hyperinsulinemic, euinsulinemic clamp or hyperglycemic clamp procedures in patients with type 2 diabetes, where the muscles were central site of metformin action [27]. In animals, metformin increases muscle glucose takeover stimulated by insuline, resulting in a glycogen synthesis increase and the glucose oxidation in peripheral tissues, but not in increasing the production of lactate [31].

Metformin also increases the takeover and oxidation of glucose in adipose tissue, and equally well encourages lipogenesis [32]. However, the metformin in vitro effect in 
the peripheral tissues depends on the amount of its concentration, so it's very slow at the beginning. Metformin increases insulin binding to its receptors by increasing the phosphorylation and the tyrosine kinase activity on the insulin receptors in vivo, so this could lead to a reduction in plasma glucose, which could not be reproduced in vitro [33]. It also increases the possibility of translocation of the GLUT-1 and GLUT-2 glucose transporter isoforms in various types of cells [34] and thus prevents the occurrence of the insulin resistance in hepatocytes and adipocytes cultures, which are exposed to high concentrations of insulin for a longer period of time [35].

In the case of long-term use, metformin reduces the concentration of plasma lipoproteins (particularly triglycerides, and, to a lesser degree, cholesterol) in patients with hyperlipoproteinemia, especially Type IV, and II-B [36]. It is considered to be the drug of choice in obese patients with type 2 diabetes, primarily because it does not increase the body weight of patients, but on the contrary, it can reduce adipose tissue [29].

A significant contribution to the elucidation of the mechanism of the metformin action was given by Zhou et al 2001 [37]. They showed that metformin activates the hepatic and muscle adenosine monophosphate-activated protein kinase (AMPK), an enzyme that normally resides adenosine monophosphate-activated, being result of the adenosine triphosphate decomposition. AMPK also gets triggered by the cell signaling for increased energy requirements. Hepatic AMPK activation results in phosphorylation and inhibition of acetyl coenzyme A carboxylase, which catalyzes lipogenesis. Since furthermore there is a blockage in the synthesis of adipose acids, their oxidation is being stimulated. In addition, the activation of hepatic AMPK reduces the expression of a sterol-regulatory elementbinding-protein-1 (SREBP-1), normally an important transcription factor that participates in the pathogenesis of insulin resistance, dyslipidemia, and type 2 diabetes. Reduction of SREBP-1 expression leads to a decrease of gene expression of the lipogenic enzymes that later contribute to the reduction of synthesis of triglycerides and hepatic steatosis occurence.

However, it must be noted that although there is a common view that metformin reduces obesity, with special emphasis on visceral obesity in patients with type 2 diabe- tes, there is a lack of studies that could confirm this and / or possibly show the correlation of the reduction of abdominal visceral obesity with a parallel increase in insulin sensitivity, glikoregulation recovery or dislipoproteinemia correction in type 2 diabetes patients.

In our earlier work, we showed that in obese type 2 diabetes patients, metformin reduces unproductive fast insulin secretion and increases its productive postprandial secretion [38]. It also increases the suppression of gluconeogenesis by insulin and lowers glucagonstimulated gluconeogenesis [30]. Metformin increases takeover and oxidation of glucose inadipose tissue [32]. Under the action of metformin in omental adipocytes, the expression of SREBP-1 inhibits with an increase in AMPK [39].

All these mechanisms of metformin action, showed that it has a great potential in reducing visceral obesity that combines with insulin resistance. The metformin impact on AMPK increase and SREBP-1 inhibition in visceral adipose tissue, is particularly highlighted in the review reports as a potentially important mechanism in the prevention and reduction of cardiovascular risk in patients with type 2 diabetes and insulin resistance [40].

On the other hand, there are few and contradictory reports about the impact of other oral antidiabetics on the visceral obesity in patients with type 2 diabetes. There are only individual detailed reports that certain drugs called insulin sensitizers, such as thiazolidinediones, after the first three months of application in patients with type 2 diabetes, although leading to a reduction in $\mathrm{HbAlc}$ levels, lead to an increase in overall obesity, increase of subcutaneous adipose tissue, with no changes in visceral obesity [23]. Our previous results indicate that the three-month application of metformin in obese patients with type 2 diabetes, and patients with impaired glucose tolerance more often led to normalization of $\mathrm{HbAlc} \mathrm{lev-}$ els in patients with pretherapy level of $\mathrm{HbAlc}$ $<8 \%$ compared to patients with $\mathrm{HbAlc} \geq 8 \%$ $[41,42]$.

\section{FURTHER ACTION}

In spite of the clear implications that metformin is the drug of choice in the treatment of obese patients with type 2 diabetes, there is a lack of the pharmacoepidemiological and clinical studies that document the effects 
of metformin on the redistribution of body adipose as well as its impact on the reduction of abdominal and / or visceral obesity. Generally speaking, the effects of oral antidiabetic agents in different forms of obesity are imperative for further research, as the current good clinical practice reduced to monitoring of metabolic and anthropometric variables that define obesity, including abdominal obesity, without the actual insight into the visceral obesity.

\section{ACKNOWLEDGMENT}

I am thankful for lingustic corrections of this text to Ana D. Vuković, language and literature professor.

\section{REFERENCES}

1. Heilbronn L, Smith SR, Ravussin E. Failure of fat cell proliferation, mitochondrial function and fat oxidation results in ectopic fat storage, insulin resistance and type II diabetes mellitus Int J Obes Relat Metab Disord 2004;28(Suppl 4):S12-21.

2. Dubois SG, Heilbronn LK, Smith SR, et al. Decreased expression of adipogenic genes in obese subjects with type 2 diabetes. Obesity 2006;14:15431552.

3. Bays HE, Gonzalez-Campoy JM, Bray GA, et al. Pathogenic potential of adipose tissue and metabolic consequences of adipocyte hypertrophy and increased visceral adiposity. Expert Rev Cardiovasc Ther 2008;6:343-368.

4. Bays HE, Gonzalez-Campoy JM, Henry RR, et al. Is adiposopathy (sick fat) an endocrine disease? Int J Clin Pract 2008;62:1474-1483.

5. MiyatakeN, Takenami S and FujiiM. Evaluation of visceral adipose accumulation in Japanese women and establishment of a predictive formula. Acta Diabetol 2004;41:113-117.

6. Catalano KJ, Stefanovski D, Bergman RN. Critical Role of the Mesenteric Depot Versus Other Intra-abdominal Adipose Depots in the Development of Insulin Resistance in Young Rats. Diabetes 2010;59:1416-1423.

7. Lakka TA, Lakka HM, Salonen $R$ and et al. Abdominal obesity is associated with accelerated progression of carotid atherosclerosis in men. Atherosclerosis 2001;154:497-504.

8. Frayn $\mathrm{KN}$. Visceral fat and insulin resistance causative or correlative? British Journal of Nutrition 2000;83( Suppl1):S71-S77.

9. Widen E, Lehto M, Kanninen T, et al. Association of polymorphism in the $\mathrm{B} 3$-adrenergic receptor gene with features of the insulin resistance syndrome in Finns. N Engl J Med 2004;333:348-351.
10. Yokota T, Oritani K, Takahashi I, et al. Adiponectin, a new member of the family of soluble defense collagens, negatively regulated the growth of myelomonocytic progenitors and the functions of macrophages. Blood 2000;96:1723-1732.

11. Steppan CM, Bailey ST, Bhat S, et al.The hormone resistin links obesity to diabetes. Nature 2001;409:307-312.

12. Fried SK, Bunkin DA, Greenberg AS. Omental and subcutaneous adipose tissues of obese subjects release interleukin-6: depot difference and regulation by glucocorticoid. Journal of Clinical Endocrinology and Metabolism 1998;83:847-850.

13. Kraja AT, Province MA, Arnett D, et al. Do inflammation and procoagulation biomarkers contribute to the metabolic syndrome cluster? Nutrition \& Metabolism 2007; 4:28-39.

14. Montague CT, Prins JB, Sanders L, et al. Depotrelated gene expressionin human subcutaneous and omental adipocytes. Diabetes 1998;47:1384-1391.

15. Aldhahi W, Hamdy O. Adipokines, inflammation, and the endothelium in diabetes.Curr Diab Rep2003;3(4):293-298.

16. Prada PO, Ropelle E, Mourao RH, et al. REGFR Tyrosine Kinase Inhibitor (PD153035) Improves Glucose Tolerance and Insulin Action in High-Fat DietFed Mice. Diabetes 2009;58(12):2010-2019.

17. Fukuhara A, Matsuda M, Nishizawa $M$, et al. Visfatin: a protein secreted by visceral fat that mimics the effects of insulin. Science 2005;307:426-430.

18. Brambilla P, Bedogni G, Moreno LA, et al. Crossvalidation of anthropometry against magnetic resonance imaging for the assessment of visceral and subcutaneous adipose tissue in children.International Journal of Obesity 2006;30:23-30.

19. Stanforth PR, Jackson AS, Green JS, et al. Generalized abdominal visceral fat prediction models for black and white adults aged 17-65 y: the HERITAGE Family Study. International Journal of Obesity 2004;28:925-932.

20. St-Pierre J, Lemieux I, Perron P, et al. Relation of the "hypertriglyceridemic waist" phenotype to earlier manifestations of coronary artery disease in patients with glucose intolerance and type 2 diabetes mellitus. Am J Cardiol 2007;99(3):369-373.

21. Gastaldelli A. Abdominal fat: does it predict the development of type 2 diabetes? American Journal of Clinical Nutrition 2008;87(5):1118-1119.

22. Fujimoto WY, Jablonski KA, Bray GA, et al. Body size and shape changes and the risk of diabetes in the diabetes prevention program. Diabetes 2007;56:1680-1685.

23. Kim SK, Hur KY, Kim HJ, et al. The increase in abdominal subcutaneous fat depot is an independent factor to determine the glycemic control after rosiglitazone treatment. Eur J Endocrinol 
2007;157(2):167-174.

24. UK Prospective Diabetes Study (UKPDS) Group: Intensive blood glucose control with sulphonylureas or insulin compared with conventional treatment and risk of complication in patients with type 2 diabetes (UKPDS 33). Lancet 1998;352:837-853.

25. UK Prospective Diabetes Study (UKPDS) Group: Effect of intensive blood glucose control with metformin on complication in overweight patients with type 2 diabetes (UKPDS 34). Lancet 1998;352:854865.

26. Bailey CJ, Turner RC. Metformin.N Engl J Med 1996;334(9):574-579.

27. Nathan DM, Buse JB, Davidson MB, et al. Medical Management of Hyperglycemia in Type 2 Diabetes: A Consensus Algorithmfor the Initiation and Adjustment of Therapy Diabetes Care 2009;32(1):193203.

28. Bailey CJ. Metformin - an update. Gen Pharmacol 1993;24:1299-1309.

29. Stumvoll M, Nurjhan N, Perriello G, Dailey G, Gerich JE. Metabolic effects of metformin in noninsulin-dependent diabetes mellitus. N Engl J Med 1995;333:550-554.

30. Wollen N, Bailey CJ. Inhibition of hepatic gluconeogenesis by metformin: synergism with insulin. Biochem Pharmacol 1988;37:4353-4358.

31. Rossetti L, DeFronzo RA, Gherzi R, et al. Effect of metformin treatment on insulin action in diabetic rats: in vivo and in vitro correlations. Metabolism 1990;39:425-435.

32. Galuska D, Nolte LA, Zierath JR, WallbergHenriksson $\mathrm{H}$. Effect of metformin on insulin-stimulated glucose transport in isolated skeletal muscle obtained from patients with NIDDM. Diabetologia 1994;37:826-832.

33. Cigolini M, Bosello O, Zancanaro C, Orlandi PG, Fezzi O, Smith U. Influence of metformin on metabolic effect of insulin in human adipose tissue in vitro. Diabet Metab 1984;10:311-315.

34. Matthaei S, Hamann A, Klein HH, et al. Asosciation of metformin's effect to increase insulin-stimulated glucose transport with potentiation of insulin induced translocation of glucose transporters from intracellular pool to plasma membrane in rat adipocytes. Diabetes 1991;40:850-857.

35. Kozka IJ, Holman GD. Metformin blocks downregulation of cell surface GLUT4 caused by chronic insulin treatment of rat adipocytes. Diabetes 1993;42:1159-1165.

36. Schneider J, Erren T, Zöfel P, Kaffarnik H. Metformin induced changes in serum lipids, lipoproteins, and apoproteins in non-insulin-dependent diabetes mellitus. Atherosclerosis 1990;82(1-2):97103.
37. Zhou G, Myers R, Li Y, et al. Role ofAMP-acitvated protein kinase in mechanism of metformin action. J Clin Invest2001;108(8):1167-1174.

38. Vuković M, Lapčević M, Kalezić N, Gvozdenović $B$. The effect of metformin on fasting and postprandial insulin secretion in obese patients with diabetes mellitus type 2. Srp Arh Celok Lek 2007;(6-8): 447-452.

39. Oikari S, Ahtialansaari T, Heinonen MV, et al. Downregulation of PPARs and SREBP by acyl-CoAbinding protein overexpression in transgenic rats. Pflügers Archiv European Journal of Physiology 2008;456(2):369-377.

40. LimCT, Kola B, Korbonits M. AMPK as a mediator of hormonal signaling. Journal of Molecular Endocrinology 2010;44:87-97.

41. Vukovic M, Gvozdenovic BS. Clusters of patients with Diabetes Mellitus typ 2 treated with Metformin. The Serbian Journal of General Practice 2008; (12):32-36

42. Lapčević $M$, Vuković $M$, Dimitrijević I, Kalezić $\mathrm{N}$, Ristić J. The effect of medicamentous and nonmedicamentous therapy on lowering risk factors for cardiovascular and cerebrovascular episodes in an interventional study. Srp Arh Celok Lek 2007;9-10: 554-561. 


\title{
Uloga metformina u tretmanu dijabetesa tipa $2 \mathbf{i}$ gojaznosti
}

\author{
Mira H. Vuković \\ Centar za edukaciju, Opšta bolnica Valjevo, Valjevo, Srbija
}

\section{KRATAK SADRŽAJ}

Tema: Međusobna udruženost i proučavanje povezanosti između gojaznosti, visceralne gojaznosti, smanjene osetljivosti na insulin (sa posledičnom hiperinsulinemijom), dijabetesa tip 2, dislipoproteinemija i antropometrijskih karakteristika pacijenata sa metaboličkim sindromom, predmet su mnogih epidemioloških studija. Međutim, primećuje se da postoji neslaganje i kontradiktornost u definisanju antropometrijskih i metaboličkih faktora rizika za nastanak kardiovaskularnih, cerebrovaskularnih i drugih vaskularnih oboljenja, posebno u populaciji gojaznih pacijenata sa dijabetesom tip 2.

Pozicioniranost teme u medicinskoj javnosti: Teorijski, metformin postiže dobru glikoregulaciju upravo kod visceralno gojaznih bolesnika. Ovo se objašnjava većom glikometaboličkom aktivnošću visceralnog masnog tkiva u odnosu na supkutanu mast.

Buduće aktivnosti: Efikasnija redukcija visceralnog masnog tkiva kod pacijenata sa postignutom boljom glikoregulacijom pod uticajem metformina, rezultat je njegovih kompleksnih mehanizama dejstva. Metformin igra važnu ulogu u smanjenju kardiovaskularnog rizika koji potiče od povišene visceralne gojaznosti, paralelno sa postizanjem dobre glikoregulacije kod gojaznih bolesnika sa dijabetesom tip 2 .

Ključne reči: metformin, dijabetes, tip 2, gojaznost, masno tkivo 